\title{
Loyalitas Konsumen: Implikasi dari Diferensiasi Produk dan Nilai Emosional
}

\author{
Dita Amanah ${ }^{1 *}$, Dedy Ansari Harahap ${ }^{2}$ \\ ${ }^{1}$ Universitas Negeri Medan \\ Jalan Willem Iskandar/Pasar V Medan 20221, Indonesia \\ ${ }^{2}$ Universitas Islam Sumatera Utara \\ Jalan Sisingamangaraja No. 16 Medan, Indonesia \\ *email:ditamnh@yahoo.com
}

\begin{tabular}{c}
\hline Artikel Info \\
\hline Received: \\
9 Maret 2019 \\
Revised: \\
24 Maret 2019 \\
Accepted: \\
30 Maret 2019 \\
\hline
\end{tabular}

\begin{abstract}
ABSTRAK
Tujuan penelitian ini untuk menganalisis peran diferensiasi produk dan nilai emosional terhadap loyalitas konsumen di Lazada Indonesia. Sampel pada penelitian ini berjumlah 150 mahasiswa Fakultas Ekonomi dan Bisnis Universitas Pendidikan Indonesia dengan purposive sampling sebagai teknik penarikan sampel. Mereka adalah mahasiswa yang berbelanja online lebih dari dua kali di Lazada. Secara parsial diferensiasi produk tidak memiliki pengaruh terhadap loyalitas mahasiswa, nilai emosional memiliki pengaruh signifikan terhadap loyalitas mahasiswa. Secara simultan diferensiasi produk dan nilai emosional secara simultan memiliki pengaruh signifikan terhadap loyalitas mahasiswa pada Lazada Indonesia, kemampuan diferensiasi produk dan nilai emosional menjelaskan loyalitas mahasiswa pada Lazada Indonesia sangat terbatas.
\end{abstract}

Kata Kunci: Loyalitas konsumen, nilai emosional, lazada, diferensiasi produk

Customer Loyalty: Implications of Product Differentiation and Emotional Value

\begin{abstract}
The purpose of this research is to analyze the role of product differentiation and emotional value on Customer loyalty in Lazada Indonesia. The sample in this study amounted to 150 students of the Faculty of Economics and Business, Universitas Pendidikan Indonesia with purposive sampling as a sampling technique. They are students who shop online more than twice at Lazada. Partially product differentiation has no effect on student loyalty, emotional value has a significant effect on student loyalty. Simultaneously product differentiation and emotional value simultaneously have a significant influence on student loyalty to Lazada Indonesia, the ability of product differentiation and emotional value to explain student loyalty to Lazada Indonesia is very limited.
\end{abstract}

Keywords: Customer loyalty, emotional value, lazada, product differentiation.

Cara Sitasi :

Amanah, D., Harahap, D. A., (2019). Loyalitas Konsumen: Implikasi dari Diferensiasi Produk dan Nilai Emosional. Jurnal Ilmiah Manajemen dan Bisnis, 20(1), 15-26. https://doi.org/10.30596/jimb.v20i1.2991. 


\section{PENDAHULUAN}

Persaingan yang begitu ketat diantara perusahaan yang berada pada industri dan bidang yang sama dewasa ini, menjadikan setiap perusahaan berusaha melakukan pengembangan dan memajukan usahanya. Perusahaan berupaya untuk menciptakan dan menawarkan produk yang berbeda dengan pesaing disamping juga tetap menjaga kualitas produk tersebut. Pencapaian keberhasilan tentu sangat diinginkan oleh setiap perusahaan pada era persaingan ini. Perusahaan harus dapat memahami keinginan dan kebutuhan pelanggan untuk memenangkan persaingan. Berorientasi kepada pelanggan dan memberikan nilai yang lebih besar kepada mereka justeru akan menciptakan nilai lebih kepada perusahaan dan selanjutnya akan dapat menjadi pemenang di pasar.

Evaluasi secara terus menerus terhadap produk yang dimiliki perlu dilakukan perusahaan untuk menciptakan strategi yang tepat untuk diimplemantasikan. Salah satu strategi yang dilakukan perusahaan untuk terus mengembangkan produknya adalah diferensiasi produk. Diferensiasi produk adalah tindakan merancang serangkaian perbedaan yang berarti untuk membedakan tawaran perusahaan dengan tawaran pesaing. Diferensiasi produk dapat dibedakan menjadi bentuk, fitur, mutu kinerja, mutu kesesuaian, daya tahan, keandalan, mudah diperbaiki (Kotler \& Keller, 2016). Diferensiasi produk bertujuan untuk memotivasi perusahaan melakukan pembedaan produk mereka dengan pesaing. Jadi, modifikasi produk yang substantif sangat diperlukan dan ini yang menjadi manfaat dilakukannya diferensiasi produk. Diferensiasi dalam bentuk, desain, gaya dan kualitas diharapkan dapat menarik konsumen untuk melakukan keputusan pembelian terhadap produk tersebut dan seterusnya setia untuk menggunakannya. Produk yang unik dan sulit untuk ditiru adalah salah satu keberhasilan diferensiasi produk. Selain itu juga akan membentuk persepsi positif di benak konsumen akan produk dan citra perusahaan.

Selain diferensiasi produk, terdapat faktor lain yang dapat mempengaruhi konsumen untuk tetap setia membeli pada toko tertentu, yaitu nilai emosional. Era digital dewasa ini dimana bisnis online sudah menjadi tren, maka perusahaan dituntut untuk mampu menumbuhkan emosi positif sehingga ketika suatu produk digunakan atau dikonsumsi akan memberikan kepuasan tersendiri bagi konsumennya. Keunggulan tersebut diharapkan dapat menguatkan nilai emosional pelanggan dalam loyalitas konsumen. Emosi merujuk pada suatu perasaan dan pikiran yang khas, suatu keadaan biologis dan psikologis dan serangkaian kecenderungan untuk bertindak baik dikarenakan rangsangan dari luar maupun dari dalam individu. Nilai emosional adalah adanya ikatan emosional antara pelanggan dan produsen setelah pelanggan menggunakan barang atau jasa yang diberikan oleh pemasok (Boxer \& Rekettye, 2010). Nilai emosional begitu berpengaruh terhadap loyalitas pelanggan seperti pengalaman yang menyenangkan atau ada faktor lain yang membentuk emosi positif konsumen. Pelanggan yang loyal merupakan kunci sukses suatu bisnis. Mempertahankan pelanggan yang loyal merupakan prioritas yang paling utama selain mendapatkan pelanggan baru. Pelanggan baru bukan hal yang mudah untuk diperoleh dan membutuhkan biaya yang tidak sedikit, maka sangatlah rugi bila perusahaan melepas pelanggan yang loyal begitu saja. Jadi, faktor emosional memiliki pengaruh yang cukup unik dalam keputusan pembelian karena terkait dengan perilaku konsumen (Amanah dan Purba, 2012).

Berdasarkan iPrice Group - detikInet, 2017, Lazada Indonesia menjadi toko online terpopuler sepanjang 2017. Seiring dengan bertambahnya pesaing di bisnis online, Lazada tetap menjadi toko online yang paling 
banyak dicari dan sering dikunjungi konsumen. Oleh karena itu banyak faktor yang perlu dievaluasi Lazada untuk dapat mempertahankan konsumen yang loyal, diantaranya kedua variabel yang didiskusikan pada penelitian ini (diferensiasi produk dan nilai emosional).

Hasil penelusuran peneliti diperoleh bahwa penelitian loyalitas konsumen terkait diferensiasi produk dan nilai emosional belum dilakukan. Penelitian yang ada selama ini adalah analisis diferensiasi produk dilakukan secara parsial terhadap loyalitas konsumen, demikian juga halnya dengan nilai emosional dan itupun masih jarang yang meneliti toko online sebagai objek penelitiannya. Dikarenakan keterbatasan penelitian relevan tersebut maka peneliti tidak menemukan referensi internasional yang sesuai untuk membahas pengaruh parsial diferensiasi produk terhadap loyalitas konsumen dan pengaruh simultan diferensiasi produk dan nilai emosional terhadap loyalitas konsumen. Oleh sebab itu peneliti tertarik untuk mengeksplorasi mengenai loyalitas konsumen dari sudut pandang diferensiasi produk dan nilai emosional secara bersamaan. Dengan demikian studi ini diharapkan dapat memberikan kontribusi pada perkembangan ilmu pemasaran khususnya mengenai loyalitas konsumen yang menambah referensi baru pada penelitian ini.

Diferensiasi produk adalah penciptaan suatu produk baik yang nyata maupun yang dipersepsikan. Perbedaan produk ini sebenarnya kecil sehingga pemasar harus menggunakan satu bauran yang kreatif untuk menciptakan citra yang unik dan menarik (Donavan dkk, 2016). Strategi diferensiasi produk dapat menjadi alat keunggulan bersaing perusahaan untuk menyediakan produk yang memberikan kepuasan kepada pelanggan karena memenuhi kebutuhan mereka. Kualitas produk menjadi pembeda utama dibanding pesaing (Shammot M M, 2011). Diferensiasi ditujukan pada pasar luas yang melibatkan penciptaan produk yang unik. Keistimewaan ini dapat dikaitkan dengan desain, citra merek, teknologi, fitur, dealer, jaringan atau layanan pelanggan. Diferensiasi adalah strategi yang layak untuk mendapatkan pengembalian di atas rata-rata dalam bisnis tertentu karena loyalitas merek yang dihasilkan menurunkan sensitivitas pelanggan terhadap harga. Peningkatan biaya biasanya dapat diteruskan kepada pembeli. Loyalitas pembeli juga dapat berfungsi sebagai penghalang masuk dimana perusahaan baru harus mengembangkan kompetensi khas mereka sendiri untuk membedakan produk mereka dengan cara tertentu agar dapat berhasil dalam persaingan (Tanwar, 2013).

Dapat disimpulkan bahwa diferensiasi produk merupakan kegiatan memodifikasi produk menjadi menarik dan juga sebagai suatu strategi perusahaan untuk memperkenalkan produk mereka kepada produk kompetitor dengan berbagai cara seperti desain produk, merek, kemasan, ukuran dan rasa. Perlu kreativitas tinggi untuk menciptakan produk yang unik, lebih menarik, lebih aman dan nyaman bagi konsumen. Namun, apabila mampu melakukannya, maka perusahaan akan memenangkan persaingan. Indikator diferensiasi produk menurut (Armstrong dkk, 2017) adalah bentuk, keistimewaan, mutu kinerja, mutu kesesuaian, daya tahan, gaya.

Menurut (Sweeney \& Soutar, 2001) nilai emosional adalah utilitas yang berasal dari perasaan atau afektif/emosi positif yang ditimbulkan dari mengkonsumsi produk. Terjadi trade off antara persepsi pelanggan terhadap kualitas atau manfaat produk dan pengorbanan yang dilakukan melalui harga yang dibayarkan (Petrick \& Backman, 2002). Nilai emosional menciptakan perasaan positif pada pelanggan pada saat membeli atau menggunakan produk tertentu (Tjiptono, 2015). Pelanggan membayangkan nilai yang pernah diterimanya ketika menggunakan produk tertentu (Woodruff, 1997). Tidak saja organisasi yang beorientasi keuntungan perlu 
untuk memperhatikan nilai pelanggan. Organisasi sektor publik juga berupaya memberikan nilai terbaik kepada pelanggan. Warnaby \& Finney (2005) menganalisis nilai yang dirasakan pengunjung terhadap loyalitas pada British Library. Peneliti menyatakan British Library perlu mempertimbangkan pendekatan yang lebih berorientasi pemasaran yang fokus kepada pemberian nilai lebih kepada pengunjung untuk pengembangan perpustakaan. Keunggulan kompetitif secara berkelanjutan akan tercipta melalui klarifikasi dan komunikasi proposisi nilai kepada target pasar (pengunjung perpustakaan).

Nilai emosional (emotional value) merupakan perasaan yang dialami konsumen berkaitan dengan perilaku setelah pembelian. Perusahaan dituntut untuk memberikan pengalaman menyenangkan agar konsumen puas akan produk dan jasa yang ditawarkan oleh perusahaan (Schmitt, 2010). Indikator nilai emosional yaitu penciptaan nilai sendiri, kepuasan, kenyamanan, keindahan, gengsi (prestise) (Sweeney \& Soutar, 2001).

Menurut Griffin (2009) loyalitas konsumen adalah komitmen untuk bertahan secara mendalam untuk melakukan pembelian ulang atau berlangganan kembali produk atau jasa tertentu secara konsisten di masa akan datang, meskipun pengaruh situasi dan usahausaha pemasaran mempunyai potensi untuk menyebabkan perubahan perilaku. Pelanggan yang loyal akan melakukan pembelian berulang secara teratur, membeli berbagai lini produk atau jasa lain, memberi referensi kepada orang lain dan penolakan terhadap

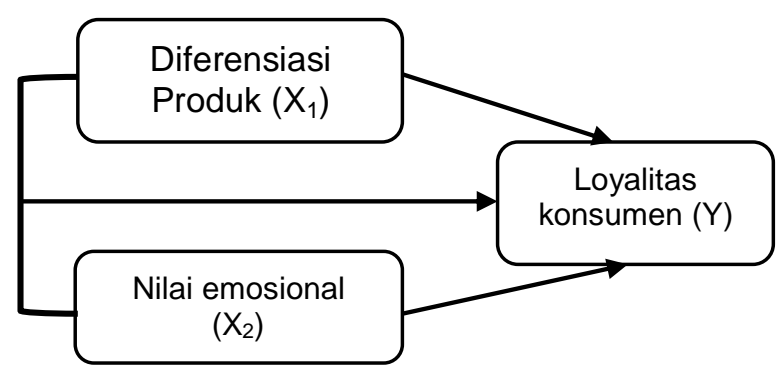

Gambar 1. Kerangka Pemikiran produk atau jasa pesaing. Konsep ini lebih mengarah kepada perilaku dibandingkan dengan sikap. Pelanggan yang loyal akan memperlihatkan perilaku pembelian dengan pola yang teratur dan dalam waktu yang lama serta cenderung bersikap positif terhadap penyedia jasa dan hanya mempertimbangkan akan menggunakan jasa tertentu ketika muncul kebutuhan (Rai \& Srivastava, 2014). Keinginan konsumen yang kuat untuk membeli kembali produk atau jasa tertentu di masa akan datang (Amanah, 2011) disebabkan oleh pengaruh pemasar untuk merubah perilaku pelanggan merupakan bentuk kualitas pelayanan (Oliver, 1999). Oleh karena itu, setiap perusahaan berupaya menjadikan pelanggannya loyal dengan interkasi dua arah dan saling tukar informasi secara intens antara perusahaan-pelanggan (Harahap, 2006).

Dapat disimpulkan bahwa loyalitas terbentuk melalui berbagai tahapan sesuai dengan proses pembelajaran dan penyediaan produk. Loyalitas pelanggan dipengaruhi secara positif oleh kepuasan setelah mengkonsumsi produk tertentu serta akan membentuk komitmen dan kepercayaan pelanggan terhadap produk tersebut. Tjiptono (2012) menyatakan indikator untuk mengukur loyalitas konsumen yaitu kebiasaan mengkonsumsi barang/jasa tersebut, selalu menyukai produk tersebut, pembelian ulang, tetap memilih produk tersebut, merekomendasikan produk/jasa tersebut kepada orang lain.

\section{METODE}

Penelitian yang digunakan adalah kuantitatif yaitu melakukan penelitian secara sistematis mengenai fenomena yang terjadi pada pembelian online serta hubungannya. Penelitian ini dilakukan di Universitas Pendidikan Indonesia dengan responden berjumlah seratus lima puluh orang yang merupakan mahasiswa Fakultas Ekonomi dan Bisnis. Teknik pengambilan sampel yang digunakan adalah sampel bertujuan 
(purposive sampling) yaitu mahasiswa Fakultas Ekonomi dan Bisnis yang loyal terhadap toko online Lazada yaitu yang sudah melakukan belanja online lebih dari dua kali. Responden terlebih dahulu ditanya apakah sudah pernah melakukan pembelian di Lazada lebih dari dua kali, jika menjawab iya maka peneliti memberi kuesioner untuk selanjutnya diisi oleh responden. Hasil penyebaran kuesioner dan pengumpulan data, diperoleh 150 kuesioner yang kembali dan layak untuk dianalisis. Kuesioner digunakan sebagai instrumen penelitian yang disebar kepada responden dalam memperoleh data yang diperlukan. Jenis kuesioner adalah tertutup dimana peneliti memiliki daftar pertanyaan dengan alternatif jawaban yang tersedia dalam skala Likert (1-5) yaitu 1 (sangat tidak setuju), 2 (tidak setuju), 3 (kurang setuju), 4 (setuju), 5 (sangat setuju). Analisis regresi linier berganda adalah teknik analisis data yang digunakan pada penelitian ini untuk mengukur intensitas hubungan antara dua variabel (dependen dan independen) yang dalam studi ini yaitu variabel diferensiasi produk dan nilai emosional terhadap loyalitas konsumen. Selain itu juga melakukan prediksi nilai variabel dependen (loyalitas konsumen) atas variabel independen (diferensiasi produk dan nilai emosional).

\section{HASIL DAN PEMBAHASAN}

Sebelum dilakukan pengujian hipotesis, maka terlebih dahulu dilakukan uji validitas menggunakan korelasi product moment dengan 17 pertanyaan, diperoleh seluruh item pada variabel diferensiasi produk mempunyai klasifikasi valid dikarenakan $r_{\text {hitung }}>r_{\text {tabel }}$ $(0,1603)$. 9 pertanyaan variabel nilai emosional mempunyai klasifikasi valid sehingga dapat digunakan sebagai alat untuk memperoleh data responden. 9 pertanyaan, variabel loyalitas konsumen mempunyai klasifikasi valid sehingga dapat digunakan sebagai alat untuk memperoleh data responden. Setelah indikator dinyatakan valid, maka dilanjutkan dengan uji reliabilitas menggunakan Cronbach Alpha, dimana hasil yang diperoleh pada variabel diferensiasi sebesar 0,802 , nilai emosional sebesar 0,717 dan loyalitas konsumen sebesar 0,1603, maka ketiga variabel tersebut dapat dinyatakan reliabel karena $>0.7$.

Indikator yang digunakan pada penelitian ini dinyatakan valid dan reliabel, maka selanjutnya adalah melakukan uji asumsi klasik, sebagai salah satu kriteria sebelum melakukan teknik analisa data menggunakan regresi linier berganda. Hasil pengujian asumsi klasik yang dilakukan adalah dengan uji normalitas, uji heteresdekositas dan multikolinieritas, dan penelitian ini memenuhi kriteria uji asumsi klasik, sehingga dapat dilanjutkan dengan teknik analisis regresi berganda.

Hasil analisis regresi linier berganda yang dipresentasikan menunjukkan persamaan regresi adalah $\mathrm{Y}=2,933-0,177$ $\mathrm{X}_{1}+0,450 \mathrm{X}_{2}+\mathrm{e}$.

Tabel 1. Hasil Analisis Regresi Linier Berganda

\begin{tabular}{|c|c|c|c|c|c|c|c|c|}
\hline \multicolumn{9}{|c|}{ Coefficients $^{a}$} \\
\hline \multirow[t]{2}{*}{ Model } & \multirow{4}{*}{$\begin{array}{l}\text { (Constant) } \\
\text { Diferensiasi } \\
\text { produk } \\
\text { Nilai }\end{array}$} & $\begin{array}{r}\text { Unsta } \\
\text { Coe }\end{array}$ & $\begin{array}{l}\text { dardized } \\
\text { icients }\end{array}$ & $\begin{array}{l}\text { Standardized } \\
\text { Coefficients }\end{array}$ & $t$ & Sig. & $\begin{array}{l}\text { Colline } \\
\text { Statist }\end{array}$ & $\begin{array}{l}\text { rity } \\
\text { cs }\end{array}$ \\
\hline & & $\begin{array}{c}\mathbf{B} \\
2,933\end{array}$ & $\begin{array}{c}\text { Std. Error } \\
, 451\end{array}$ & Beta & 6,499 & ,000 & Tolerance & VIF \\
\hline \multirow[t]{2}{*}{1} & &,- 177 & ,086 &,- 148 & 2,061 & ,041 & 1,000 & 1,000 \\
\hline & & , 450 & ,069 & , 467 & 6,498 & ,000 & 1,000 & 1,000 \\
\hline
\end{tabular}

a. Dependent Variable: Loyalitas konsumen 
Dengan demikian dapat diinterpretasi dari persamaan regresi pada Tabel 1 adalah jika semua variabel bebas (diferensiasi produk dan nilai emosional) memiliki nilai nol (0) maka nilai variabel terikat (loyalitas konsumen) sebesar 2,933. Nilai koefisien diferensiasi produk untuk variabel $\mathrm{X}_{1}$ sebesar 0,177 dan bertanda negatif. ini menunjukkan bahwa diferensiasi produk mempunyai hubungan yang berlawanan arah dengan loyalitas konsumen. Hal ini mengandung arti bahwa setiap kenaikan satu satuan diferensiasi produk maka variabel loyalitas konsumen (Y) akan menurun sebesar 0,177 dengan asumsi bahwa variabel bebas yang lain dari model regresi adalah tetap. Nilai koefisien nilai emosional untuk variabel $\mathrm{X}_{2}$ sebesar 0,450. Hal ini mengandung arti bahwa setiap kenaikan satu satuan nilai emosional maka variabel loyalitas konsumen (Y) akan naik sebesar 0,450 dengan asumsi bahwa variabel bebas yang lain dari model regresi adalah tetap.

Tabel 1, dapat diketahui untuk menguji secara parsial Hipotesis 1: pada kolom Coefficients model 1 terdapat nilai sig 0,041. Nilai sig lebih kecil dari nilai probabilitas 0,05 , atau nilai $0,041<0,05$, maka $\mathrm{H}_{1}$ diterima dan Ho ditolak. Variabel $\mathrm{X}_{1}$ mempunyai $\mathrm{t}_{\text {hitung }}$ yakni $-2,061$ dengan $\mathrm{t}_{\text {tabel }}=0,198$. Jadi $\mathrm{t}_{\text {hitung }}<\mathrm{t}_{\text {tabel }}$ dapat disimpulkan bahwa variabel $\mathrm{X}_{1}$ memiliki kontribusi terhadap $Y$. Nilai $t$ negatif menunjukkan bahwa variabel $\mathrm{X}_{1}$ mempunyai hubungan yang berlawanan arah dengan $\mathrm{Y}$. Jadi dapat disimpulkan diferensiasi produk tidak memiliki pengaruh signifikan terhadap loyalitas konsumen. pada kolom Coefficients model 1 terdapat nilai sig 0,000. Nilai sig lebih kecil dari nilai probabilitas 0,05 , atau nilai $0,000<0,05$, maka $\mathrm{H}_{1}$ diterima dan Ho ditolak. Variabel $\mathrm{X}_{2}$ mempunyai $\mathrm{t}_{\text {hitung }}$ yakni 6,498 dengan $\mathrm{t}_{\text {tabel }}$ $=0,198$. Jadi $t_{\text {hitung }}>t_{\text {tabel }}$ dapat disimpulkan bahwa variabel $\mathrm{X}_{2}$ memiliki kontribusi terhadap Y. Nilai $t$ positif menunjukkan bahwa $X_{2}$ mempunyai hubungan yang searah dengan Y. Jadi dapat disimpulkan nilai emosional memiliki pengaruh signifikan terhadap loyalitas konsumen.

Tabel 2. Hasil Uji Simultan

\begin{tabular}{llccccc}
\hline Model & & Sum of Squares & df & Mean Square & F & Sig. \\
\hline \multirow{2}{*}{1} & Regression & 6,010 & 2 & 3,005 & 23,510 &, $000^{\mathrm{b}}$ \\
& Residual & 18,789 & 147 &, 128 & & \\
& Total & 24,799 & 149 & & & \\
\hline
\end{tabular}

a. Dependent Variable: Loyalitas konsumen

b. Predictors: (Constant), Nilai emosional, Diferensiasi produk

Tabel 2 diperoleh nilai $F_{\text {hitung }}$ sebesar 23,510 dengan nilai probabilitas $(\operatorname{sig})=0,000$. Nilai $F_{\text {hitung }}(23,510)>F_{\text {tabel }}(3,06)$, dan nilai sig. lebih kecil dari nilai probabilitas 0,05 atau nilai $0,000<0,05$; maka $\mathrm{H}_{1}$ diterima, berarti secara simultan diferensiasi produk dan nilai emosional berpengaruh signifikan terhadap loyalitas konsumen.

Sedangkan hasil Koefisien determinasi pada penelitian ini menunjukkan bahwa diferensiasi produk dan nilai emosional berpengaruh sebesar $24,2 \%$ terhadap loyalitas konsumen, sedangkan $75,8 \%$ dipengaruhi variabel lain yang tidak diteliti. Karena nilai $\mathrm{R}$ square dibawah 50\% maka dapat disimpulkan kemampuan variabel-variabel independen dalam menjelaskan variabel dependen amat terbatas.

\section{Pembahasan \\ Pengaruh Diferensiasi Produk terhadap Loyalitas}

Hasil studi ini menyatakan bahwa diferensiasi produk bernilai negatif dan tidak berpengaruh terhadap loyalitas konsumen terhadap Lazada. Ini dibuktikan dari nilai $\mathrm{t} \mathrm{X}_{1}$ 
yaitu -1,642. Hasil ini didukung oleh Utami (2016) yang meneliti mengenai diferensiasi (produk, pelayanan, citra) terhadap loyalitas konsumen. Ditemukan bahwa diferensiasi produk dan diferensiasi pelayanan berpengaruh negatif dan tidak signifikan terhadap loyalitas konsumen, sementara diferensiasi citra berpengaruh positif dan signifikan terhadap loyalitas konsumen pada restoran Pizza Hut Medan. Di sisi lain, hasil penelitian ini tidak sejalan dengan (Dejawata et al, 2014) yang menyatakan bahwa terdapat pengaruh signifikan diferensiasi produk terhadap loyalitas konsumen dengan beta coefficient $(\beta)$ 0,586 ( $\mathrm{p}$-value <0,05). Juga bertentangan dengan Muntaha, Sutrisna, \& Widya (2018), yang menganalisis pengaruh diferensiasi (produk, pelayanan, citra) terhadap loyalitas konsumen pada PT. Pos Indonesia di Pekanbaru. Hasil menunjukkan bahwa secara parsial dan simultan diferensiasi (produk, pelayanan, citra) memiliki pengaruh terhadap loyalitas konsumen. Artinya konsumen menghendaki PT. Pos memiliki produk yang berbeda dari pesaing yang sifatnya lebih spesial dan diinginkan konsumen seperti lebih murah, lebih cepat, lebih baik yang menciptakan nilai yang lebih tinggi dibanding pesaing. Sama juga halnya dengan diferensiasi pelayanan dan citra yang dituntut konsumen untuk memiliki pelayanan dan citra yang berbeda dengan pesaing.

Argumen mengenai tidak adanya pengaruh dan hasil yang negatif diferensiasi produk terhadap loyalitas mahasiswa adalah dikarenakan rata-rata toko online di Indonesia menyediakan dan menawarkan produk yang hampir sama. Oleh karena itu, hasil penelitian ini logis dengan fakta yang ada dimana mahasiswa sebagai konsumen tidak menjadikan diferensiasi produk pertimbangan utama untuk loyal kepada Lazada. Beberapa faktor yang dapat mempengaruhi loyalitas konsumen diuraikan pada bagian rekomendasi artikel ini.

\section{Pengaruh Nilai Emosional terhadap Loyalitas}

Berbeda dengan hasil analisis untuk pengaruh nilai emosional terhadap loyalitas mahasiswa. Ditemukan pengaruh yang positif dan signifikan nilai emosional terhadap loyalitas mahasiswa dengan nilai $\mathrm{t} \mathrm{X}_{2}$ yaitu 5,808. Ini sejalan dengan Chang \& Wang (2011) yang menguji pengaruh kualitas pelayanan elektronik, nilai persepsi pelanggan dan kepuasan terhadap loyalitas konsumen dalam lingkungan belanja online. Hasil menunjukkan bahwa kualitas pelayanan elektronik dan nilai persepsi pelanggan mempengaruhi kepuasan dan kemudian mempengaruhi loyalitas pelanggan. Mereka juga menemukan terdapat rute (cara berfikir) emosional dan rasional yang mempengaruhi loyalitas pelanggan dalam proses belanja online di Taiwan. Penelitian mereka memberi konstribusi yang menjelaskan proses yang mempengaruhi motivasi dan perilaku pembeli online. Juga didukung oleh Yaya dkk, (2015) yang menyatakan bahwa nilai yang diperolah konsumen mempengaruhi loyalitas nasabah dari layanan bank online di Spanyol. Jadi, perbaikan layanan secara keseluruhan dapat digunakan untuk meningkatkan kepuasan dan nilai nasabah dan seterusnya menciptakan loyalitas. Penelitian lain justeru bertolak belakang dengan hasil penelitian ini. Koupai et al (2015) menemukan bahwa nilai yang diterima konsumen tidak mempengaruhi loyalitas nasabah Bank Agrikultural online di Iran. Mereka menyampaikan beberapa rekomendasi seperti sosialisasi dan pelatihan gratis yang dilakukan oleh manajer dan otoritas bank kepada nasabah dikarenakan sifat baru layanan elektronik di negara berkembang dan nasabah yang kurang mahir menggunakan semua fitur intenet bank. Rekomendasi kedua adalah merancang desain internet bank yang sederhana sehingga nasabah dengan berbagai tingkatan pendidikan dapat menggunakannya. Argumen mengenai adanya pengaruh positif dan signifikan nilai emosional terhadap loyalitas mahasiswa adalah karena Lazada dianggap memiliki nilai positif lebih dibanding pesaing 
seperti memberi ongkos kirim gratis kepada pembeli, pengiriman barang yang tepat waktu, kemiripan gambar di website dengan produk asli serta testimoni pembeli yang sudah menggunakan produk. Jadi hal positif ini yang menjadikan mahasiswa tetap loyal untuk berbelanja di Lazada.

Belanja online menciptakan berbagai nilai belanja, dimana nilai utilitarian dan nilai pengalaman memiliki pengaruh terhadap kepuasan dan mengarah kepada peningkatan loyalitas konsumen (Lee, 2005). Pendekatan secara terintegrasi mengenai nilai dalam belanja online ditemukan pada penelitiannya. Temuan juga memberikan dukungan teoritis untuk mengadopsi pendorong nilai yang lebih besar dalam studi perilaku konsumen. Nilai yang dipersepsikan konsumen dipengaruhi oleh hiburan dan kepercayaan konsumen terhadap website yang ditampilkan oleh toko online selain kelengkapan yang tersedia. Oleh karena itu perlu dilakukan peningkatan kualitas informasi pada website seperti mendesain perangkat yang dapat menghibur dan menarik serta mudah difahami dan dinikmati konsumen selama berbelanja pada toko online tertentu (Kim \& Niehm, 2009).

Nilai yang dirasakan memiliki pengaruh yang sangat besar pada perilaku pelanggan, karena itu mempengaruhi keputusan pada pilihan produk, niat beli dan pembelian berulang. (Krasna, 2008) menganalisis peran nilai yang dirasakan konsumen sebagai alat pemasaran untuk memastikan loyalitas pelanggan dalam industri hotel Slovenia, dimana mengetahui dan memahami keinginan dan harapan tamu memainkan peran penting dalam industri perhotelan. Dengan cara pemasaran kualitatif, dipastikan bahwa pelaku bisnis perhotelan Slovenia tidak berbeda secara umum dari pelaku bisnis perhotelan lainnya. Inilah sebabnya mereka mencoba mengekspos karakteristik yang paling dihargai oleh tamu hotel. Mereka memberikan penekanan besar pada seni kuliner, penciptaan perasaan seperti di rumah dan pengalaman tamu yang terintegrasi.
Perilaku konsumen sangat dipengaruhi oleh nilai kondisional, dalam konteks dimana layanan digunakan, diikuti oleh komitmen yang dapat ditingkatkan dengan membangun nilai emosional dan nilai kondisional dengan berfokus pada penawaran pelayanan pengalaman yang menyenangkan dalam konteks yang benar. (Pura, 2005) menganalisis pengaruh langsung dari dimensi nilai yang dipersepsikan (harga, kenyamanan, sosial, emosional, kondisional dan epistemik) terhadap komponen loyalitas sikap dan perilaku: komitmen dan niat perilaku untuk menggunakan layanan seluler berbasis lokasi di Finlandia. Hasil ini memperkenalkan konsep-konsep baru dan mengembangkan nilai multidimensi yang dirasakan konsumen dan model loyalitas. Hasil memberikan implikasi praktis tentang bagaimana meningkatkan kesadaran layanan berbasis lokasi (LBS) dengan cara memberikan gambaran realistis tentang bagaimana LBS menciptakan nilai bagi pelanggan.

(Berraies et al, 2017) juga menguji pengaruh dari nilai yang dirasakan (kualitas, harga, emosional, sosial) dari aplikasi mobile banking (MB) terhadap kepercayaan pelanggan, kepuasan elektronik dan kesetiaan pelanggan. Selain itu mereka juga menyelidiki peran usia pelanggan yang memoderasi antara nilai yang dirasakan dari aplikasi MB dan kepercayaan elektronik. Hasil penelitian menyatakan bahwa nilai (kualitas, harga dan emosional) dari aplikasi MB adalah prediktor kepercayaan pelanggan dan usia berperan sebagai moderator dalam hubungan nilai yang dirasakan dengan kepercayaan elektronik. Temuan juga menunjukkan bahwa kepercayaan elektronik memiliki pengaruh positif pada kepuasan elektronik dan kesetiaan elektronik.

Mempertimbangkan emosi yang dialami konsumen selama penyediaan layanan adalah penting. Emosi memiliki pengaruh langsung pada loyalitas. Semakin kuat emosi positif yang dialami konsumen, maka konsumen akan semakin loyal (Bloemer 


\section{Published April 2019 \\ JURNAL ILMIAH MANAJEMEN DAN BISNIS \\ ISSN 1693-7619 (print) | ISSN 2580-4170 (online), http://jurnal.umsu.ac.id/index.php/mbisnis}

\& de Ruyter, 1999). Kompetensi emosi karyawan toko sangat mempengaruhi emosi konsumen dan membantu membina hubungan yang baik dengan konsumen. Ketika hubungan baik sudah terbina maka akan menciptakan loyalitas konsumen terhadap toko (Delcourt dkk, 2013).

\section{Pengaruh Diferensiasi Produk dan Nilai Emosional terhadap Loyalitas}

Hasil menunjukkan diferensiasi produk dan nilai emosional memiliki pengaruh secara simultan terhadap loyalitas konsumen. Ini sejalan dengan (Khalid \& Helander, 2006) yang menyatakan bahwa pelanggan butuh akan desain produk yang menarik, oleh karena itu perusahaan harus fokus terhadap penciptaan produk berdasarkan fungsionalitas dan utilitasnya. Keberhasilan produk di pasar sangat ditentukan oleh daya tarik estetisnya, kesenangan yang diciptakan produk, sehingga memberi kepuasan dan menciptakan kesetiaan pelanggan. Emosi mempengaruhi bagaimana pelanggan berinteraksi dengan produk dan penting dalam menentukan potensi penjualan produk. Pengukuran emosi didasarkan kepada siklus hidup pengembangan produk. Kebutuhan pelanggan dan emosi diukur untuk menentukan proses desain produk yang bertujuan untuk menghasilkan produk yang menyenangkan dan memuaskan pelanggan. Kepuasan pelanggan yang berkelanjutan akan menciptakan loyalitas terhadap produk yang ditawarkan perusahaan. Selain desain, menciptakan merek yang berbeda juga penting di era persaingan ini. Perusahaan mencoba untuk membentuk hubungan antara konsumen dengan merek pada tingkat sensual dan emosional sehingga diharapkan akan muncul keterikatan yang lebih dalam, tahan lama dan kuat bagi konsumen terhadap merek tersebut (Akgün dkk, 2013). Hubungan emosional antara konsumen dan merek menghasilkan peningkatan komitmen (Grisaffe \& Nguyen, 2011), kepuasan pelanggan (Bagozzi, dkk, 1999), loyalitas, dan niat pembelian kembali (Ersoy \& Calik, 2000).

Merek yang memiliki ciri berbeda akan menciptakan emosi yang juga berbeda pada konsumen. (Loureiro dkk, 2012) melakukan analisis konsumen terhadap kecintaan tiga merek mobil yaitu Toyota, Ford dan Renault. Hasil menunjukkan bahwa keterikatan merek secara positif terkait dengan kecintaan merek. Kecintaan terhadap merek produk tertentu akan memperkuat kepercayaan, minat untuk melanjutkan hubungan dan keyakinan akan masa depan merek tersebut. Hal ini selanjutya akan menciptakan loyalitas untuk tetap menggunakan atau mengkonsumsi merek produk tersebut.

\section{SIMPULAN}

Berdasarkan hasil analisis regresi linier berganda, diperoleh adanya pengaruh positif dan signifikan nilai emosional terhadap loyalitas mahasiswa pada Lazada Indonesia. Namun ditemukan tidak adanya pengaruh diferensiasi produk terhadap loyalitas mahasiswa pada Lazada Indonesia. Hasil ini tidak membuktikan penelitian (Dejawata et al., 2014) yang menyatakan bahwa terdapat pengaruh signifikan diferensiasi produk terhadap loyalitas konsumen Cafe Bunchbead Kota Malang. Juga tidak membuktikan penelitian Muntaha et al (2018) yang berpendapat bahwa diferensiasi produk mempengaruhi loyalitas konsumen pada PT. Pos Indonesia. Artinya, diferensiasi produk tidak menjadi pertimbangan utama mahasiswa untuk loyal pada Lazada Indonesia karena pada umumnya toko online di Indonesia menyediakan produk yang sejenis. Hasil penelitian ini diharapkan memberikan sumbangan pemikiran kepada pemasar online khususnya Lazada Indonesia untuk memfokuskan kepada penciptaan nilai emosional konsumen, yang merupakan faktor penentu utama terhadap loyalitas konsumen pada penelitian ini. Peneliti selanjutnya diharapkan mengikutsertakan variabel lain yang dapat mempengaruhi loyalitas 
konsumen pada toko online seperti kualitas pelayanan, kualitas produk, kualitas situs web, kepercayaan, keamanan dan sebagainya. Selain itu juga disarankan untuk memperluas sampel penelitian yang tidak hanya fokus pada mahasiswa dan sekaligus menambah jumlahnya. Metode penelitian yang berbeda yang mungkin lebih tepat juga disarankan agar hasil penelitian selanjutnya lebih maksimal.

\section{REFERENSI}

Akgün, A. E., Koçoğlu, İ., \& İmamoğlu, S. Z. (2013). An Emerging Consumer Experience: Emotional Branding. In Procedia - Social and Behavioral Sciences (Vol. 99, pp. 503-508). https://doi.org/10.1016/j.sbspro.2013.10 .519

Amanah, Dita dan Purba, A. F. (2012). Pengaruh Produk Dan Faktor Emosional Konsumen Terhadap Keputusan Pembelian Sepeda Motor Yamaha. Niagawan, 1(1), 45-54.

Amanah, D. (2011). Pengaruh Promosi dan Brand Image (Citra Produk) Terhadap Loyalitas Pembelian Produk Pepsodent di Ramayana Plaza Jalan Aksara Medan . Keuangan \& Bisnis, 3(3), 221-233.

Armstrong, G., Kotler, P., \& Opresnik, M. O. (2017). Marketing An Introduction (Global Edi). Pearson International.

Bagozzi, R. P., Gopinath, M., \& Nyer, P. U. (1999). The Role of Emotions in Marketing. Journal of Academy of Marketing Science, 27(2), 184-206. https://doi.org/10.13140/RG.2.1.3777.1 921

Berraies, S., Ben Yahia, K., \& Hannachi, M. (2017). Identifying the effects of perceived values of mobile banking applications on customers. International Journal of Bank Marketing, 35(6), 1018-1038.

https://doi.org/10.1108/ijbm-09-20160137

Bloemer, J., \& de Ruyter, K. (1999).
Customer Loyalty in High and Low Involvement Service Settings: The Moderating Impact of Positive Emotions. Journal of Marketing Management, 15(4), 315-330. https://doi.org/10.1362/0267257997848 70388

Boxer, I., \& Rekettye, G. (2010). The influence of perceived emotional intelligence on the perceived service value and customer loyalty. Acta Oeconomica, 60(3), 275-293. https://doi.org/10.1556/AOecon.60.201 0.3 .3

Dejawata, T. B., Kumadji, S., \& Abdillah, Y. (2014). Pengaruh Diferensiasi Produk Terhadap Kepuasan Pelanggan Dan Loyalitas Pelanggan(Survei pada Pelanggan "Cake in Jar" Cafe Bunchbead Kota Malang). Jurnal Administrasi Bisnis, 17(2), 1-8.

Delcourt, C., Gremler, D. D., Van Riel, A. C. ., \& Van Birgelen, M. (2013). Effects of perceived employee emotional competence on customer satisfaction and loyalty The mediating role of rapport. Journal of Service Management, 24(1), 5-24. https://doi.org/http://dx.doi.org/10.1108 /MRR-09-2015-0216

Donavan, T., Minor, M. S., \& Mowen, J. C. (2016). Consumer Behavior. Chicago: Business Press.

Ersoy, N. F., \& Calik, N. (2000). Brand Loyalty: Emotional Devotion or Rational Behavior - A Study on Mobile Telephones from Eskisehir Turkey. The Business Review, 15(1), 212-219.

Griffin, J. (2009). Taming the search-andswitch customer: earning customer loyalty in a compulsion-to-compare world (1st ed.). San Francisco, CA: Jossey Bass.

Grisaffe, D. B., \& Nguyen, H. P. (2011). Antecedents of emotional attachment to brands. Journal of Business Research, 64(10), 
https://doi.org/10.1016/j.jbusres.2010.1 1.002

Harahap, D. A. (2006). Hubungan Kualitas dan Loyalitas Nasabah Jasa Perbankan PT. Bank Rakyat Indonesia (Persero), Tbk Kota Medan. Program Pascasarjana Syiah Kuala Banda Aceh. https://doi.org/10.17605/OSF.IO/UGK4 Z

Hsin Chang, H., \& Wang, H. W. (2011). The moderating effect of customer perceived value on online shopping behaviour. Online Information Review (Vol. 35). https://doi.org/10.1108/1468452111115 1414

iPrice Group - detikInet. (2017). Persaingan e-Commerce Indonesia di 2017, Siapa Terpopuler?

Khalid, M. H., \& Helander, G. M. (2006). Customer emotional needs in product design. Concurrent Engineering Research and Applications, 14(3), 197206.

https://doi.org/10.1177/1063293X06068 387

Kim, H., \& Niehm, L. S. (2009). The Impact of Website Quality on Information Quality, Value, and Loyalty Intentions in Apparel Retailing. Journal of Interactive Marketing, 23(3), 221-233. https://doi.org/10.1016/j.intmar.2009.04 .009

Kotler, P., \& Keller, K. L. (2016). A Framework For Marketing Management.

Koupai, M. R., Alipourdarvish, Z., \& Sardar, S. (2015). Effects of trust and Perceived value on customer loyalty by mediating role of customer satisfaction and mediating role of customer habit ( case study: Agricultural internet bank customers in Tehran ), 2(1), 102-112.

Krasna, T. (2008). The influence of perceived value on customer loyalty in Slovenian hotel industry. Turizam, 12, 12-15. https://doi.org/10.5937/turizam0812012 $\mathrm{t}$
Lee, E.-J. (2005). Creating Value For Online Shoppers: Implications For Satisfaction and Loyalty. Asia Pacific Advances in Consumer Research, 6, 370.

Loureiro, S. M. C., Ruediger, K. H., \& Demetris, V. (2012). Brand emotional connection and loyalty. Journal of Brand Management, 20(1), 13-27. https://doi.org/10.1057/bm.2012.3

Muntaha, A. S., Sutrisna, E., \& Widya, C. B. (2018). Pengaruh Strategi Diferensiasi Terhadap Loyalitas Konsumen Bisnis Jasa Pengiriman Pt. Pos Indonesia (Persero) Pekanbaru. JOM FISIP, 5(1), $1-15$.

Oliver, R. L. (1999). Whence Consumer Loyalty? Journal of Marketing, 63(May), 33-44.

Petrick, J. F., \& Backman, S. J. (2002). An examination of the construct of perceived value for the prediction of golf travelers' intentions to revisit. Journal of Travel Research, 41(1), 3845.

https://doi.org/10.1177/0047287502041 001005

Pura, M. (2005). Linking perceived value and loyalty in location-based mobile services. Managing Service Quality, 15(6), 509-538. https://doi.org/10.1108/0960452051063 4005

Rai, A. K., \& Srivastava, M. (2014). Customer Loyalty: Concept, Context and Character. New Delhi: Mc Graw Hill Education.

Schmitt, B. (2010). Experience Marketing: Concepts, Frameworks and Consumer Insights. Foundations and Trends ${ }^{\circledR}$ in Marketing, 5(2), 55-112. https://doi.org/10.1561/1700000027

Shammot M M. (2011). Quality Management Practices and Their Impact on Organizational Performance, and Customer Behavior. European Journal of Economics, Finance and Administrative Sciences, 34(2), 21-33. 


\section{JURNAL ILMIAH MANAJEMEN DAN BISNIS ISSN 1693-7619 (print) | ISSN 2580-4170 (online), http:///iurnal.umsu.ac.id/index.php/mbisnis}

Sweeney, J. C., \& Soutar, G. N. (2001). Consumer perceived value: The development of a multiple item scale, 77, 203-220.

Tanwar, R. (2013). Porter's Generic Competitive Strategies. IOSR Journal of Business and Management, 15(1), 11-17. https://doi.org/10.9790/487X1511117

Tjiptono, F. (2012). Pemasaran Strategik. Yogyakarta: Andi.

Tjiptono, F. (2015). Strategi Pemasaran (4th ed.). Yogyakarta: Andi.

Utami, D. A. (2016). Pengaruh Strategi Diferensiasi Terhadap Loyalitas Konsumen Melalui Kepuasan Konsumen Pada Restoran Pizza Hut Di Medan. Universitas Sumatera Utara.

Warnaby, G., \& Finney, J. (2005). Creating customer value in the not-for-profit sector: A case study of the British Library. International Journal of Nonprofit \& Voluntary Sector Marketing, 10(3), 183-195. https://doi.org/10.1002/nvsm.18

Woodruff, R. B. (1997). Customer value: The next source for competitive advantage. Academy of Marketing Science, 25(2), 139-153.

Yaya, L. H. P., Marimon, F., \& Casadesus, M. (2015). The Mechanisms through Which Certain Variables Influence Customer Loyalty: The Mediating Roles of Perceived Value and Satisfaction. Human Factors and Ergonomics in Manufacturing \& Service Industries, 25(6), 627-637. https://doi.org/10.1002/hfm 